\title{
National Occupational Research Agenda
}

\section{Update J uly, 1997}




\section{NORA Teams}

Bold type indicates team leader(s)

\section{Allergic \& Irritant Dermatitis}

Boris Lushniak (NIOSH)

Alan Moshell (National Institute of Arthritis and Musculoskeletal and Skin Diseases)

Carol Burnett (NIOSH)

David Bernstein (University of Cincinnati)

Frances Storrs (Oregon Health Sciences University)

G. Frank Gerberick (Proctor \& Gamble Company)

Mark Boeniger (NIOSH)

Michael Luster (NIOSH)

Raymond Biagini (NIOSH)

Richard Fenske (University of Washington)

Stephen Berardinelli (NIOSH)

Susan Wilburn (American Nurses Association)

Albert Munson (NIOSH)

J ames J ohnson (Lawrence Livermore National Laboratory)

\section{Asthma \& Chronic Obstructive} Pulmonary Disease

\section{Kathleen Kreiss (NIOSH)}

Robert Castellan (NIOSH)

David Wegman (University of Massachusetts, Lowell

Edward L. Petsonk (NIOSH)

Hillel Koren (Environmental Protection Agency)

J effery Fedan (NIOSH)

J ohn Balmes (University of California San Francisco)

Paul Henneberger (NIOSH)

Phillip Morey (AQS Services)

Susan Kennedy (University of British Columbia)

Suzanne Hurd (National Heart, Lung and Blood Institute)

Gail Wienmann (National Heart, Lung and Blood Institute)

\section{Fertility \& Pregnancy Abnormalities}

Teresa Schnorr (NIOSH)

Barbara Grajewski (NIOSH)

Coleen Boyle (National Center for Environmental Health)

Eisuke Murono (NIOSH)

Kenneth Bridbord (Fogarty International Center)

Melissa McDiarmid (University of Maryland) Michele Marcus (Emory Universisty)

Ronald Gray (I ohns Hopkins University)

Steven Schrader (NIOSH)

\section{Hearing Loss}

J ohn Franks (NIOSH)

Alton Burks (NIOSH)

Anthony Miltich (Digital Hearing Systems)

Carol Merry (NIOSH)

Daniel J ohnson (EG\&G)

Douglas Ohlin (Army Center for Health Promotion and Preventative Medicine)
Howard Hoffman (National Institute on Deafness and Communicative Disorders)

J ohn Casali (Virginia Polytechnic Institute and State University)

Patricia Brogan (Ford Motor Company)

Randy Tubbs (NIOSH)

\section{Infectious Diseases}

Robert Mullan (NIOSH)

William Denton (Denton International)

Craig Shapiro (National Center for Infectious Diseases)

Adelisa Panlilio (National Center for Infectious Diseases)

Jack Parker (NIOSH)

J oel Breman (Fogarty International Center)

J ordan Barab (American Federation of State, County and Municiple Employees)

J une Lunney (National Institute for Nursing Research)

Kent A. Sepkowitz (Memorial Sloan-Kettering Cancer Center)

Naresh Chawla (Food and Drug Administration)

Teresa Seitz (NIOSH)

Yvette Davis (National Center for HIV, Sexually Transmitted Disease, and TB Prevention)

Yvonne Boudreau (NIOSH)

\section{Musculoskeletal Disorders}

Larry Fine (NIOSH)

Barbara Silverstein (State of Washington Department of Labor and Industries)

Brian Peacock (General Motors Corporation)

Bruce Bernard (NIOSH)

Cherie Fairfield Estill (NIOSH)

Hongwei Hsiao (NIOSH)

J ames Panagis (National Institute of Arthritis and Musculoskeletal and Skin Diseases)

LaMont Byrd ( International Brotherhood of Teamsters)

Laura Welch (George Washington University)

Priscilla Shoemaker (American Health Care Association)

Sean Gallagher (NIOSH)

Sue Schurman (George Meany Center for Labor Studies)

Thomas Slavin (Navistar International Transportation Corporation)

Thomas Leamon (Liberty Mutual Insurance Company)

Vernon Putz Anderson (NIOSH)

\section{Traumatic Injuries}

\section{Nancy Stout (NIOSH)}

William Borwegen (Service Employees International Union)

Bradley Rein (Department of Agriculture)

George Conway (NIOSH)

Gordon Reeve (Ford Motor Company)

Gordon Smith (J ohns Hopkins University)

Herbert Linn (NIOSH)

Jane Roemer (National Safety Council)

Karl Snyder (NIOSH)

Lisa Steiner (NIOSH)

Lynn J enkins (NIOSH)

Nancy McWilliams (American Society of Safety Engineers)
Rolf Eppinger (National Highway Transportation Safety Administration)

Stephen Luchter (National Highway Transportation Safety Administration)

Tim Pizatella (NIOSH)

8. Indoor Environment

Mark Mendell (NIOSH)

William Fisk (Lawrence Berkeley Laboratory)

William Cain (University of California San Diego)

Cynthia Hines (NIOSH)

Darryl Alexander (American Federation of Teachers)

David Spannbauer (General Services Administration)

Donald Milton (Harvard University)

Hal Levin (Hal Levin and Associates)

J ohn Girman (Environmental Protection Agency)

Kathleen Kreiss (NIOSH)

Marilyn Fingerhut (NIOSH)

Kenneth Wallingford (NIOSH)

Paul Jensen (NIOSH)

\section{Mixed Exposures}

Frank Hearl (NIOSH)

Alan Lunsford (NIOSH)

Robert Herrick(Harvard University)

Carlos Marentes (Rural Coalition)

Daniel Lewis (NIOSH)

Douglas Trout (NIOSH)

Gregory Burr (NIOSH)

Henry Gardner (Army Center for Environmental Health Research)

Hugh Hansen (Agency for Toxic Substance and Disease Registry)

J ohn Bucher (National Institute of Environmental Health Sciences)

Manuel Gomez (American Industrial Hygiene Association)

Vera Kommineni (NIOSH)

\section{Emerging Technologies}

Theodore Schoenborn (NIOSH)

David Conover (NIOSH)

Elaine Cullen (NIOSH)

J ack Finklea (National Center for Injury Control and Prevention)

J effery Welsch (NIOSH)

Kennith Brock (Safety Management Consultant)

Max Keifer (NIOSH)

Nicholas Ashford (Massachusetts Institute of Technology)

Raymond Lovett (West Virginia University)

Richard Hartle (NIOSH)

Tai Chan (General Motors Corporation)

\section{Control Technology \& Personal} Protective Equipment

\section{Fredrick Kissell (NIOSH)}

William Kojola (Laborers' Health and Safety Fund)

William Heitbrink (NIOSH)

Dale Avery (NIOSH)

Daniel Shipp (Industrial Safety Equipment Association) 


\section{NIOSH Vision}

Delivering on the Nation's promise:

safety and health at work for all

people...through research and

prevention.

\section{NORA Vision}

No single organization has the resources necessary to conduct occupational safety and health research to adequately serve the needs of workers in the United States. These constraints mandate that the entire occupational safety and health community engage in collaboration and coordination of its resources. The National Institute for Occupational Safety and Health (NIOSH) and its public and private partners developed the National Occupational Research Agenda (NORA) to provide a framework to guide occupational safety and health research into the next decade-for NIOSH and the entire occupational safety and health community.

\section{Message from NIOSH}

The creation of the National Occupational Research Agenda (NORA) over a year ago was truly a cooperative effort. The National Institute for Occupational Safety and Health (NIOSH) relied heavily on the expertise and input of our partners in the public and private sector to create an agenda to guide occupational safety and health research into the next decade. Over the last year, we have had many successes and learned much as we undertook the monumental task of implementing the Research Agenda.

One of the most exciting aspects of NORA implementation is the enthusiasm and support we continue to receive from our partners. This is probably best exemplified in the makeup of the NORA teams. Teams include members of academia, professional associations, NIOSH, other Government agencies, industry, and labor. We would personally like to thank all NORA team members. Their commitment and diligence are helping to drive the implementation process.

The Liaison Committee has also played a critical role in guiding the NORA implementation efforts. The committee has assisted with continued outreach, tracking and measuring our progress, and facilitating research in a number of areas.

This document provides an overview of NORA and our progress since the Agenda was unveiled one year ago. We appreciate and look forward to the continued involvement and support of the occupational safety and health community in this important effort.

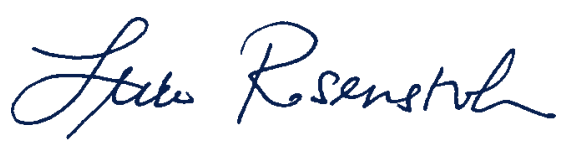

\section{Linda Rosenstock, M.D., M.P.H. \\ Director}

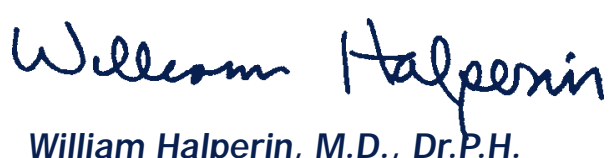

Deputy Director 


\section{Liaison Committee}

Robin Baker

American Public Health Association

Jordan Barab

American Federation of State, County and Municipal Employees

Thomas F. Bresnahan American Society of Safety Engineers

William B. Bunn

Navistar International Transportation

Corporation

Tai Chan

General Motors Corporation

Gwendolyn Puryear Keita American Psychological Association

Heidi Klein

National Association of County and City Health Officials

\section{Sandra Lange}

National Institute of Environmental Health Sciences

Thomas Leamon

Liberty Mutual Insurance Company

Wayne Lednar

Eastman Kodak Company

\section{Pamela Tau Lee}

Tai Community Development Center and Labor Occupational Health Program

\section{Joseph Main}

United Mine Workers of America

\section{Zackary Mansdorf}

American Industrial Hygiene Association

Joseph Mathey

Corning Incorporated

Franklin Mirer

United Auto Workers

Clifford Mitchell

American College of Occupational and

Environmental Medicine

Association of Occupational and Environmental Clinics

\section{Carolyn Phillips}

Chemical Manufacturers Association

Knut Ringen

Center to Protect Workers' Rights

J ane Roemer

National Safety Council

Margaret Seminario

AFL-CIO

\section{Frank White}

Organization Resources Counselors, Incorporated

\section{Liaison Committee Perspective}

In the last year, the NORA Liaison Committee has worked with NIOSH to begin the transformation of NORA from an ambitious concept to a practical reality. The Liaison Committee consists of members from academia, labor, industry, and professional organizations. Our role is to provide outreach and commentary on the development, progress, and direction of NORA.

Establishment of 20 NORA teams which include NIOSH staff and partners from academia, labor, industry, professional organizations, and other Government agencies has been the major focus of this past year. The teams will provide visionary leadership for their NORA area of occupational safety and health research. Their enthusiasm and activity in this first year have been remarkable.

The growth of the NORA teams is only one product of NORA. Although it is still early, it is already apparent that there has been an increase in investment in NORA research areas. This is due, in part, to changes in the research focus within NIOSH. However, there is also evidence that NORA has facilitated cooperation among Federal agencies and with industry and labor that will provide new resources for research in these high-priority areas.

No one holds a strict blueprint for how NORA will proceed. However, NORA has harnessed the enthusiasm of many, including the priority area team members and the Liaison Committee. NORA is readily catalyzing interest and research activity, which is the interim goal of NORA. This will lead to the ultimate goal of prevention of occupational injury and disease. The Liaison Committee is pleased to work with NIOSH and the occupational safety and health community in the implementation of NORA. Best wishes to all partners for continued success.

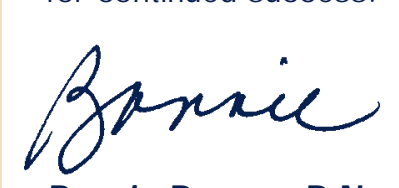

Bonnie Rogers, R.N., Ph.D.

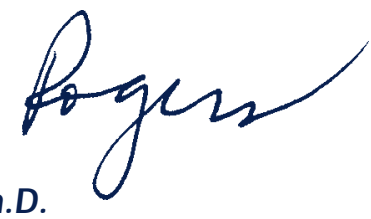

Chairperson, NORA Liaison Committee

American Association of Occupational Health Nurses 


\section{An Agenda for the 21st Century}

The National Institute for Occupational Safety and Health (NIOSH) and its partners in the public and private sectors developed the National Occupational Research Agenda (NORA) to provide a framework to guide occupational safety and health research into the next decade - not only for $\mathrm{NIOSH}$, but also for the entire occupational safety and health community. Approximately 500 organizations and individuals outside of NIOSH provided input into the development of the Agenda. This firstever attempt to guide and coordinate research nationally responds to a broadly perceived need to systematically address those topics that are most pressing and most likely to benefit workers and the Nation. Fiscal constraints on occupational safety and health research are increasing, making even more compelling the need for a coordinated and focused research agenda.

The Agenda identifies 21 research priorities (see table below). These priorities reflect a remarkable degree of concurrence among a large number of stakeholders. The NORA priority research areas are grouped into three categories: Disease and Injury, Work Environment and Workforce, and Research Tools and Approaches. The priorities are not ranked and reflect an attempt to consider both current and emerging needs.

\section{NORA Priority Research Areas}

\begin{tabular}{|c|c|}
\hline CATEGORY & PRIORITY RESEARCH AREAS \\
\hline Disease and Injury & $\begin{array}{l}\text { Allergic and Irritant Dermatitis } \\
\text { Asthma and Chronic Obstructive Pulmonary Disease } \\
\text { Fertility and Pregnancy Abnormalities } \\
\text { Hearing Loss } \\
\text { Infectious Diseases } \\
\text { Low Back Disorders } \\
\text { Musculoskeletal Disorders of the Upper Extremities } \\
\text { Traumatic Injuries }\end{array}$ \\
\hline $\begin{array}{l}\text { Work Environment and } \\
\text { Workforce }\end{array}$ & $\begin{array}{l}\text { Emerging Technologies } \\
\text { Indoor Environment } \\
\text { Mixed Exposures } \\
\text { Organization of Work } \\
\text { Special Populations at Risk }\end{array}$ \\
\hline $\begin{array}{l}\text { Research Tools } \\
\text { and Approaches }\end{array}$ & $\begin{array}{l}\text { Cancer Research Methods } \\
\text { Control Technology and Personal Protective Equipment } \\
\text { Exposure Assessment Methods } \\
\text { Health Services Research } \\
\text { Intervention Effectiveness Research } \\
\text { Risk Assessment Methods } \\
\text { Social and Economic Consequences of Workplace } \\
\quad \text { Illness and Injury } \\
\text { Surveillance Research Methods }\end{array}$ \\
\hline
\end{tabular}


Each day, an average

of 137 individuals die

from work-related

diseases, and an

additional 16 die from

injuries on the job.

Every 5 seconds a

worker is injured;

every 10 seconds a

worker is temporarily

or permanently

disabled.

Each year, about 70

youths under 18 years

of age die from

injuries at work and

64,000 require

treatment in a hospital

emergency room.

In 1995, occupational

injuries alone cost

$\$ 119$ billion in lost

wages and

productivity,

administrative

expenses, health care,

and other costs.
As we move into the next century, NORA is needed for a myriad of reasons. Two, however, stand out in importance. First, the current toll of occupational injury and illness to American workers in particular and society in general is unacceptable. Each day in the United States, an average of 137 individuals die from work-related diseases, and an additional 16 die from injuries on the job. Every 5 seconds a worker is injured; every 10 seconds a worker is temporarily or permanently disabled. Each year, about 70 youths under 18 years of age die from injuries at work and 64,000 require treatment in a hospital emergency room. In 1995, occupational injuries alone cost $\$ 119$ billion in lost wages and productivity, administrative expenses, health care, and other costs. This high toll of work injuries and illnesses is not irreversible. In fact, significant progress has been made in improving worker protection since the U.S. Congress passed the Occupational Safety and Health Act in 1970. This progress has been largely based on actionssometimes voluntary, sometimes regulatory-directed by the science and knowledge generated from occupational safety and health research.

Second, the U.S. workplace is rapidly changing. The distribution of jobs in our economy continues to shift from manufacturing to services. Longer hours, compressed workweeks, shiftwork, reduced job security, and part-time and temporary work are realities of the modern workplace. New chemicals, materials, processes, and equipment are developed and marketed at an ever accelerating pace. The workforce is also changing. As the U.S. workforce grows to an estimated 147 million by the year 2005, it will become older and more racially diverse. By the year 2005, minorities will represent $28 \%$ of the workforce and women will constitute approximately $48 \%$. These changes will present new challenges for protecting worker safety and health. NORA will help us meet these challenges in the next decade and beyond. 


\section{NORA Implementation: Update of Activities}

\section{Providing Guidance and Direction: the NORA Liaison Committee}

During the creation of NORA, there were three liaison committees (corporate, worker, and outreach) that provided outreach to individuals and organizations outside of NIOSH and assisted in the formation of the Agenda. In part because of the success of effective coordination in the development of the Agenda, it was decided that only a single liaison committee was needed in the implementation phase. The NORA Liaison Committee, chaired by Dr. Bonnie Rodgers, President, AAOHN, consists of 22 members who represent industry, labor, academia, professional organizations, and Government. The Liaison Committee has the broad and important task of assisting in the successful implementation of NORA by actively providing comments to NIOSH and its partners on the progress of NORA, providing outreach to interested stakeholders, encouraging participation in research teams, and facilitating appropriate avenues for initiating the proposed research.

\section{Partnership Teams}

Creating Partnership Teams - Partnership teams are a key part of implementing the Agenda. As envisioned last year when the Agenda was announced, these teams were to be formed to assist in the "development, pursuit, review, and dissemination of research under each NORA topic." The teams were to include a broad representation of the occupational safety and health community.

Over the past year, this vision of NORA became a reality with the formation of 20 research priority partnership teams (two priority areas - musculoskeletal disorders of the upper extremities and low back disorders - are being addressed by one team). This overall effort has brought together $121 \mathrm{NIOSH}$ researchers and 146 external partners.

The teams generally consist of a team leader and a combination of NIOSH researchers and external partners. Membership on these teams includes, among others, faculty from public and private colleges and universities, representatives of professional organizations, major manufacturing industries, leaders in the insurance industry, health and safety professionals from organized labor, and representatives from other Government agencies.

\begin{tabular}{|lr|}
\hline \multicolumn{2}{c}{ Team membership } \\
\hline Affiliations & Number \\
& \\
\hline Academia & 45 \\
\hline Labor & 16 \\
\hline Industry & 21 \\
\hline Professional organizations & 7 \\
\hline NIOSH & 121 \\
\hline CDC (non-NIOSH) & 8 \\
\hline Other Government agencies & 40 \\
\hline Other & 9 \\
\hline Total & 267 \\
\hline
\end{tabular}




\section{Research Team Activities}

The variety of activities pursued by the NORA teams reflects the diversity of the NORA research priority areas.

Disseminating Information - During the first year, a number of the teams reached out into the occupational safety and health community to raise awareness about their priority areas. For example:

- The Asthma and Chronic Obstructive Pulmonary Disease Team organized a panel of Federal partners for the March 1997 National Latex Allergy Conference and held a labor/management-sponsored workshop on the respiratory effects of metal working fluids in the automotive industry.

- The Allergic and Irritant Dermatitis Team conducted presentations at meetings of the American Contact Dermatitis Society, International Dermatoepidemiology Association, the American Academy of Dermatology, and the Universities of Pennsylvania and Washington.

- The Intervention Effectiveness Research Team prepared a manuscript that summarizes research needs for presentation at the American Public Health Association Conference later this year.

- The Traumatic Injuries Team is playing a leading role in planning the first National Injury Research Symposium to be held in October, 1997.

- The Control Technology and Personal Protective Equipment Team has been actively involved in planning a first-of-its-kind comprehensive control technology workshop in March 1998, where a more focused and ambitious action plan in this area will be developed.

Defining Issues and Research Areas - For a number of teams, the past few months have been used to better conceptualize and define the issues involved or to conduct needs assessments in their topic areas. For example:

- The Fertility and Pregnancy Abnormalities Team is conducting a needs assessment in the areas of surveillance, field studies, and toxicology.

- The Indoor Environment Team has produced a conceptual model based on categories of health effects that will help organize the diverse elements within this broad topic.

- The Mixed Exposures Team has begun to define the scope of this very complex topic and is examining mechanisms to identify and describe the most pressing research needs in the area.

- The Special Populations at Risk Team has divided into six subareas (older workers, child labor, disabled workers, women, minorities, and environmental justice) to identify operational definitions for the specific populations, specific problems, research needs, and possible outcomes and benefits of research. 
- The Organization of Work Team has focused on defining organization of work and identifying critical cross-cutting issues of work organization and other NORA priority areas.

- The Infectious Diseases Team has divided into four subgroups covering HIV, HBV and HCV, TB, and infection control and education and is focusing on research needs pertaining to these areas.

- The Emerging Technologies Team is working to define the boundaries of the health problems associated with emerging technologies and to develop an inventory of current risk analysis activities for use in a workshop that examines the effects of emerging technologies on workers.

All of the teams report progress in working together toward the common goal of focusing the efforts of the entire occupational safety and health community on the 21 NORA priorities. NIOSH remains committed to maintaining a leadership role in facilitating the activities of the NORA partnership teams.

Cementing and Expanding Partnerships - NORA brought together 500 organizations and individuals for one purpose: to create a Research Agenda. To fully implement the Agenda, multiple partnerships must be formed or continued. In addition to the partnership activities embodied in the NORA teams, NIOSH and its Federal partners have continued to build upon their commitment to NORA.

\section{Federal Partnerships}

One early success is a joint program announced between the National Institute of Arthritis and Musculoskeletal and Skin Diseases (NIAMS) and $\mathrm{NIOSH}$ to support two extramural research programs. The first initiative invites studies on repetitive motion disorders; the second, on low back pain. Federal partners also remain involved in the implementation process through membership on the partnership teams and tracking of NORA-related research activities.

A major activity for the Federal partners this year was the development of Federal baseline data to assess the overall Federal investment in NORA research priority areas during FY96. This survey was sent to all Federal partners (see listing). 


\section{Participating Federal Agencies}

FEDERAL AGENCY

Consumer Product Safety Commission

Department of Agriculture

Department of Defense

Department of Energy

Department of Health and Human Services

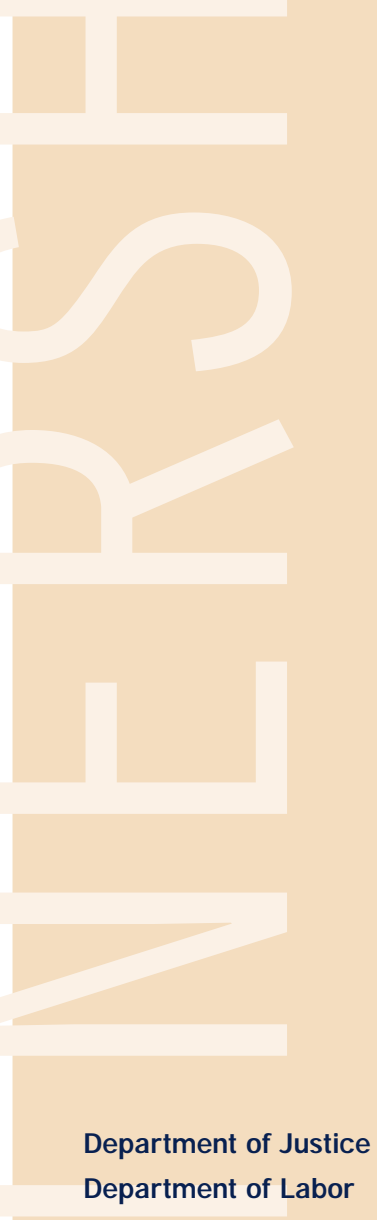

Department of Transportation

Department of Treasury

Environmental Protection Agency

Executive Office of the President

\section{OFFICE/ INSTITUTE/ DIVISION}

Directorate for Epidemiology and Health Sciences

Cooperative State Research, Education and Extension Service

Naval Medical Research and Development Command

Office of the Environment, Safety and Health

Agency for Health Care Policy and Research

Agency for Toxic Substances and Disease Registry

Centers for Disease Control and Prevention

- Epidemiology Program Office

- International Health Program Office

- National Center for Chronic Disease Prevention and Health Promotion

- National Center for Environmental Health

- National Center for Health Statistics

- National Center for HIV, Sexually Transmitted Disease, and TB Prevention

- National Center for Infectious Diseases

- National Center for Injury Prevention and Control

- National Immunization Program

- Office of Minority Health

- Office of Women's Health

- Public Health Practice Program Office

Food and Drug Administration

Health Resources and Services Administration

Intergovernmental Affairs

National Institutes of Health

- Fogarty International Center

- National Cancer Institute

- National Heart, Lung, and Blood Institute

- National Institute of Allergy and Infectious Diseases

- National Institute of Arthritis and Musculoskeletal and Skin Diseases

- National Institute of Environmental Health Sciences

- National Institute of Mental Health

- National Institute of Neurological Disorders and Stroke

- National Institute of Nursing Research

Substance Abuse and Mental Health Services Administration

National Institute of J ustice

Bureau of Labor Statistics

Mine Safety and Health Administration

Occupational Safety and Health Administration

Wage and Hour Division

Federal Aviation Administration

National Highway Traffic Safety Administration

Internal Revenue Service

National Exposure Research Laboratory

Office of Prevention, Pesticides, and Toxic Substances

Office of Science and Technology Policy

Office of Policy Development

- Domestic Policy Council 


\section{Measuring the Success of NORA}

The success of NORA will be measured over the long run by its role in effectively directing occupational safety and health research to prevent occupational illness and injury. As the NORA priorities become disseminated throughout the occupational safety and health community, this Nation should see improvements in worker safety and health. There are, however, many steps in a continuum of activities between the initial recognition that research is needed and the successful implementation of interventions that lead to prevention. To measure the success of NORA and to provide meaningful information by which to redirect or refocus NORA activities, it is necessary to identify and track progress on the continuum of activities leading to prevention. Measures that we propose to track are:

- NIOSH's research investment

- Other Federal agencies' research investment

- Funding of grant applications in NORA priority areas

- Research literature

- Prevention and intervention activities arising out of NORA

\section{Tracking NIOSH's Research Investment}

The goals of NORA include the allocation of research resources into highpriority NORA research areas. The first evidence that NORA will be successful is the redirection of resources in NIOSH's research programs, which has shown a significant increase in spending in NORA priority areas in just one year, using 1996 as a baseline (the year in which the Agenda was announced). For the data reported below, a research project was considered as NORA-related if at least $80 \%$ of project resources were committed to one of the 21 priority areas. In other words, some projects addressing NORA priority areas were not counted using this relatively strict criterion. Moreover, an independent team of NIOSH scientists determined whether projects met NORA criteria, excluding, for example, traditional cancer research and routine surveillance activities which did not have as a focus the development and testing of new research methods.

NIOSH Investment in NORA*

(in millions)

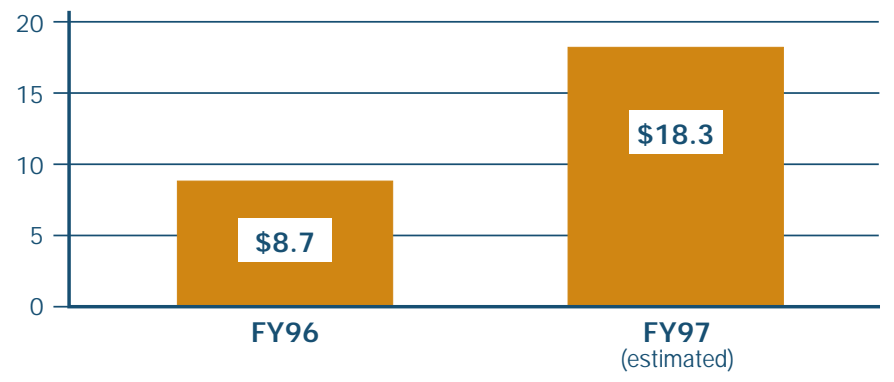

* Allocations reflect largely intramural research; extramural cooperative agreements and contracts are included, but extramural grants (which are still in the process of being funded in FY97) and training and research center activities are not included in either year . 


\section{Tracking Other Federal Agencies' Research Investment}

NIOSH and its Federal partners have designed and implemented a survey of NORA-related research investments by Federal agencies other than NIOSH. NORA-related research by these Federal partners for 1996 is estimated at almost $\$ 15$ million (out of a reported total budget of about $\$ 8$ billion).

The overall Federal investment, about \$24 million in 1996 (NIOSH and Federal partners), is the baseline against which future NORA investment will be compared.

\section{Tracking Funding of Grant Applications in NORA Priority Areas}

We expect that an early indication of increased interest in NORA area research will be increased applications for research funding. Beginning in 1997, research applications to NIOSH and select Federal partners will be tracked by NORA area. In addition, cosponsorship by NIOSH and other Federal agencies of research in NORA priority areas can be followed, such as the previously noted joint program announcement by NIAMS and NIOSH in the two musculoskeletal priority areas.

\section{Tracking the Research Literature}

Searching and reviewing the literature is an inherent part of conducting research. Bibliometrics is the quantitative assessment of the incidence, trends, and impact of published literature. It adds another dimension to the role of literature review in research. As NORA leads to greater research activity, there will be an accompanying increase in the number of publications in the priority areas. This year, NIOSH explored a number of approaches to the quantitative tracking of publications in the scientific literature. These will be pursued in specific priority areas in the future.

\section{Tracking, Prevention, and Intervention Activities Arising Out of NORA}

The ultimate success of research is in its translation into effective preventive action. We propose to measure the success of NORA by tracking awareness (e.g. information dissemination) and preventive actions that arise out of NORA activity. This may include actions by employers and workers at the work site, industry-wide adoption of control or abatement measures, intervention research, or publication and dissemination of information. Measuring these actions is a challenge; however, NIOSH and its partners are committed to defining a systematic approach to assess such impacts for at least some of the NORA priority areas in some settings. 


\section{Examples of NORA Successes}

\section{National Occupational Injury Research Symposium (NOIRS)}

NOIRS grew out of a recognition that a national research symposium on occupational traumatic injuries would not only facilitate exchange of current research information, but would also catalyze growth of interest in research regarding the prevention of traumatic occupational injuries. NOIRS is planned for October 15-17, 1997, in Morgantown, West Virginia. Response to NOIRS has been exhilarating; a large number of partners have joined with NIOSH to sponsor NOIRS. Several other NORA teams, e.g., the Risk Assessment Methods Team and the Intervention Effectiveness Research Team, have organized symposium panels on the interface between their team's work and that of the Traumatic Injuries Team.

\section{Allergic and Irritant Dermatitis}

On September 25-26, 1996, as a stepping stone for the NORA implementation phase, NIOSH sponsored the Workplace-Related Skin Diseases and Exposure Assessment Workshop to identify key workplace-related research issues and data gaps in three areas of occupational skin disease research: laboratory-based biomedical research, exposure assessment, and epidemiologic and prevention-oriented issues. Topics identified during the workshop will be the subject of future teamwork, including efforts to fill identified research gaps by facilitating research in critical areas.

\section{Latex Allergy}

During the creation of NORA, town hall meetings provided a forum for nurses and other health care providers to deliver a strong message regarding the epidemic of latex allergy among U.S. health care workers. Latex allergy is addressed in two NORA priority areas: Allergic and Irritant Dermatitis, and Asthma and Chronic Obstructive Pulmonary Disease. In addition, NIOSH formed an internal latex allergy working group to develop recommendations to prevent allergic reactions to latex in the workplace. In FY97, NIOSH will begin field, laboratory, and intervention studies of latex allergy. At the 1997 National Latex Allergy Conference, NIOSH organized a panel of key stakeholders, including the Occupational Safety and Health Administration (OSHA), Food and Drug Administration (FDA), Health Industry Manufacturers Association (HIMA), American Hospital Association (AHA), and American Nurses Association (ANA) to identify future actions for preventing latex allergy. NORA teams 
plan to stimulate the following research and prevention activities: a NIOSH cooperative agreement on exposure-response and threshold studies in the health care industry, an assessment of latex seroprevalence in the National Health and Nutrition Examination Survey (NHANES) IV, publication of National Latex Allergy Conference panel consensus recommendations, collaborative public/private funding of needed research, and a consensus standard from the American Society of Testing Methods (ASTM) to address the problem.

\section{Summary}

The first year of NORA has been encouraging because it has seen-

- The formation, commitment, and enthusiastic input of a broad-based NORA Liaison Committee.

- The formation and successful efforts of 20 NORA teams with broad-based membership.

- The participation of a large number of Federal agencies in NORA activities.

- The first survey of Federal occupational safety and health (including NORA) research investment.

- The participation of a broad array of partners in a series of activities, including conferences and symposia, in NORA priority areas.

- The evidence that a national Research Agenda was and continues to be needed and that NORA research priority areas have been well chosen.

- The recognition that NORA is a model for public-private partnerships. 


\section{Control Technology \& Personal Protective Equipment, cont.}

David de Vries (American Society of Safety Engineers)

Donald Campbell (NIOSH)

J ohn Meagher (American Industrial Hygiene Association)

Lawrence Reed (NIOSH)

Michael Flynn (University of North Carolina at Chapel Hill)

Nancy Bollinger (NIOSH)

Richard Duffy (International Association of Fire Fighters)

Sidney Soderholm (NIOSH)

Steven Mallinger (Occupational Safety and Health Administration)

Steven Berardineli (NIOSH)

Christina Gomberg (NIOSH)

\section{Organization of Work}

Steven Sauter (NIOSH)

Robert Peters (NIOSH)

David LeGrande (Communication Workers of America)

Gwendolyn Puryear Keita (American Psychological Association)

J eanne Stellman (Columbia University)

J oseph Hurrell (NIOSH)

Lawrence Murphy (NIOSH)

Lois Tetric (University of Houston)

Mary Lewis (NIOSH)

Michael Colligan (NIOSH)

Nancy Lessin (Massachusetts Coalition for Occupational Safety and Health)

Naomi Swanson (NIOSH)

William Halperin (NIOSH)

Richard Lippin (ARCO Chemical Corporation)

\section{Special Populations at Risk}

Gwendolyn Cattledge (NIOSH)

Andrea K. Taylor (United Auto Workers)

Ann Fidler (NIOSH)

Anthony Yancey (NIOSH)

Robert Rinsky (NIOSH)

Charles Lee (United Church of Christ)

Dawn Castillo (NIOSH)

Frances Henderson (Alcorn State University)

Gayle DeBord (NIOSH)

Howard Frumkin (Emory University)

J oni Barnett (National Center for Farmworker Health)

Letitia Davis (Massachusetts Department of Health)

Lorrie Cameron (NIOSH)

Pam Tau Lee (Labor Occupational Health Program)

Theodore Meinhardt (NIOSH)

\section{Cancer Research Methods}

\section{Elizabeth Ward (NIOSH)}

Ann Hubbs (NIOSH)

Carrie Redlich (Yale University)

Michael Sprinker (International Chemical Workers Union Council)

Christine Sofge (Occupational Safety and Health Administration)

David Dankovic (NIOSH)

J ames Bond (Chemical Industry Institute of Toxicology)
Mary Ann Butler (NIOSH)

Myra Karstadt (Environmental Protection Agency)

Ainsley Weston (NIOSH)

Nathaniel Rothman (National Cancer Institute)

Ronald Herbert (National Institute of Environmental Health Sciences)

\section{Surveillance Research Methods}

\section{J ohn Sestito (NIOSH)}

Alice Greife (Central Missouri State University)

Barbara Fotta (NIOSH)

William Weber (Bureau of Labor Statistics)

Robert Castellan (NIOSH)

Denise Koo (Epidemiology Program Office, Centers for Disease Control)

Diane Wagener (National Center for Health Statistics)

Earl Pollack (Center to Protect Workers' Rights)

Eric Frumin (Union of Needletrades, Industrial and Textile Trade Employees)

Henry Anderson (Wisconsin Department of Health and Social Services)

J ane McCammon (Colorado Department of Public Health and Environment)

ohn Myers (NIOSH)

Leroy Mickelson (NIOSH)

Richard Ehrenberg (NIOSH)

Steven Newell (Occupational Safety and Health Administration)

Wayne Ledner (Eastman Kodak Company)

\section{Exposure Assessment Methods}

Mary Lynn Woebkenberg (NIOSH)

Elizabeth Reh (NIOSH)

Bonnie Rogers (American Association of Occupational Health Nurses)

David Pegram (Department of Energy)

R. DeLon Hull (NIOSH)

Eric Sampson (National Center for Environmental Health)

Gary Spies (Monsanto Company)

James Weeks (George Washinton University)

Kenneth Williams (NIOSH)

Lawrence Elliott (NIOSH)

Martin Abell (NIOSH)

Michael Keane (NIOSH)

Paul Knechtges (Naval Medical Research and Development Command)

\section{Risk Assessment Methods}

Leslie Stayner (NIOSH)

William Perry (Occupational Safety and Health Administration)

William Fayerweather (Owens Corning Corporation)

William Farland (Environmental Protection Agency)

Bryan Hardin (NIOSH)

Christopher Portier (National Institute of Environmental Health Sciences)

Dale Hattis (Clark University)

Frank Mirer (United Auto Workers)

Gerald van Belle (University of Washington)

Mark Torrasson (NIOSH)

Michael Attfield (NIOSH)

James T. Wassell (NIOSH)

\section{Intervention Effectiveness Research}

Linda Goldenhar (NIOSH)

Ann Brockhaus (Organization Resource Counselors Inc.)

Anthony LaMontangne (New England Research Institutes)

Carolyn Needleman (Bryn Mawr College)

Daniel Murphy (St. Paul Fire and Marine Insurance Company)

J anet J ohnston (NIOSH)

Lawrence Chapman (University of Wisconsin)

Naomi Swanson (NIOSH)

Paul Landsbergis (Cornell University)

Paul Schulte (NIOSH)

Raymond Sinclair (NIOSH)

Robin Baker (Univesity of California Berkeley)

Sarah Glavin (General Accounting Office)

Scott Schneider (Center to Protect Workers' Rights)

Scott Earnest (NIOSH)

\section{Health Services Research}

Scott Deitchman (NIOSH)

William Bunn (Navistar International Transportation Corportation)

David Michaels (City Univerisity of New York)

Gregory Wagner (NIOSH)

Janice Klink (NIOSH)

J anie Gordon (University of Maryland)

J ay Himmelstein (University of Massachusetts)

J oan Buchanan (Harvard University)

Karen Worthington (NIOSH)

Kathleen Rest (University of Massachusetts)

Linda Rudolph (California Department of Industrial Relations)

Mary Cunnings (Agency for Health Care Policy Research)

Rosemary Sokas (Occupational Safety and Health Administration)

Thomas Hodous (NIOSH)

\section{Social \& Economic Consequences of} Workplace IIIness \& Injury

\section{Leslie Boden (Boston University)}

Ross A. Fabricant (NIOSH)

Allan Hunt (Upjohn Institute for Employment Research)

William Halperin (NIOSH)

Brian Day (NIOSH)

Chuck Levenstein (University of Massachusetts, Lowell)

Cynthia Madden (University of Washington)

Emily Spieler (West Virgina University)

Harry Shannon (Institute for Work and Health)

Lou Fintor (NIOSH)

Paul Keane (NIOSH)

Sharon Morris (University of Washington)

Theodor Miller (Pire Associates)

Thomas Camm (NIOSH)

Elyce Biddle (NIOSH) 
For additional information, contact NIOSH at:

National Institute for Occupational Safety and Health

Publications Dissemination

4676 Columbia Parkway

Cincinnati, OH 45226-1998

\section{1-800-35-NIOSH}

(1-800-356-4674)

Fax: $513-533-8573$

or visit the NIOSH homepage on the World Wide Web at http:/ / www.cdc.gov/ niosh/ homepage.html

DHHS (NIOSH) Publication No. 97-138 